Fórum rovatunkban a Közjavak folyóirat korábbi számaiban megjelent tanulmányokhoz érkezett hozzászólásokat, vitaindítókat, reflexiókat, megjegyzéseket közöljük. A közös gondolkodás alapjainak továbbépítéséhez kíván fórumot biztosítani, továbbá a közjogi kutatások aktuális kérdéseinek megvitatásához, közvetlenül teret adva az aktuális témákkal kapcsolatos hírek megjelenésének, valamint a szakmai vélemények és különböző álláspontok közlésének a különböző jogágak közötti szabad és kötetlen kommunikáció jegyében.

\title{
Ombudsmani Est az MTA KöZJogi AlbizottságGaL *
}

\author{
Bartha Ildikó - Bordás Péter ${ }^{l}$
}

Az MTA Közjogi Albizottság egyik fö célkitüzése, már megalakulása óta, hogy az Akadémia különbözö tudományterületi egységei, valamint a más szakmai szervezetek közötti tudományos diskurzus, együttmüködés létrejöttét elösegítse. 2016 öszén már e törekvés eredményeiröl is beszámoltunk; az egyik ilyen alkalom során a közigazgatási bíráskodás, míg a másikon a rendvédelem témaköre került a vita középpontjába.

2017. április 26-án 17 órától az Albizottság az Alapvető Jogok Biztosának Hivatalával (AJBH) közösen, az Ombudsmani Esték rendezvénysorozat keretében tartott szakmai beszélgetést Természeti erőforrások: A használat közössége és a közösség használata. Közszolgáltatások konfliktusai címmel az AJBH Korczak termében.

A rendezvény keretében elöször este házigazdája, Bándi Gyula (helyettes-ombudsman, ÁJBH) köszöntötte a résztvevőket, s a témához illő személyes tapasztalataival nyitotta meg azt. Majd Horváth M. Tamás, az MTA közjogi albizottság elnöke röviden összefoglalta a téma aktualitását.

Az est alapgondolata szerint verseng egymással a természeti erőforrások védelme és azoknak a közszolgáltatások révén való kihasználása. A nemzet közös örökségét képező természeti erőforrások alkotmányos védelme mellett a közszolgáltatások hozzáférésének gazdaságossági (díjfizetés) és szociális (szegények hozzáférési) szempontjainak érvényesítése is közérdekvédelem. A köztük lévő összhang megteremtése nélkül hosszú távon egyik érdek sem védhető meg, az érdekharc vesztesei mi leszünk. A jogi szabályozás sokszor olyankor is küzd ezzel a kettősséggel, amikor látszólag a szakmai (a jogászok és/vagy közgazdászok szakmai) racionalitáson belül marad. A közelmúlt példája erre az Általános közigazgatási rendtartásról szóló salátatörvény tervezete, amelyik számos ponton kimondatlanul ütközteti e sajátos közös

\footnotetext{
${ }^{*}$ DOI 10.21867/KjK/2017.2.7.

${ }^{1}$ Dr. Bartha Ildikó, egyetemi docens, DE ÁJK, MTA-DE Közszolgáltatási Kutatócsoport; Dr. Bordás Péter, tudományos segédmunkatárs, MTA-DE Közszolgáltatási Kutatócsoport
} 
örökség hosszabb távú védelmi és a rövidebb távú elhasznál(ód)ás szempontjait. És nem feledkezhetünk meg az összhangmegteremtésének örökzöld témájáról sem: az adók és a használati díjak útján való gazdasági ösztönző és fékező rendszerekről. Ezt követően tartotta meg az Albizottság három tagja, a három eltérő szempontú vitaindító hozzászólását.

Elsőként Pump Judit (c. egyetemi docens, PPKE JÁK) Lehet-e fogyasztói érdek a természeti eröforrás-védelem elmulasztása? A közösségek védelme közötti valós és látszat konfliktusok - címmel vetette fel alapvetően problémaorientált gondolatait. Egyik megoldásra váró kérdés e körben a fogyasztói megközelítés változtatása, épp a fogyasztói érdekek védelme okán. A környezeti teher és a környezeti teherviselő ugyanis számára nem mindig érzékelhető számára, így a díjak összegében sem azt fogja meglátni, hogy a hulladékhasznosítás beépülö költsége számára megtérülö kiadás lehet. Mindez természetesen kihatással van a fogyasztói döntésekre is... A fogyasztói (ügyféli) jogok kérdése is hangsúlyt kapott az előadásban, elsősorban az Akr. új szabályai kapcsán (ki lehet egyáltalán ügyfél, miként változtak jogosultságai a közigazgatási eljárásban a Ket-hez képest).

Majd egy újabb szemléletmód és konfliktushalmaz jelent meg Deák Dániel (egyetemi tanár, BCE GTK) Öko-adók az EU Bírósága gyakorlatának tükrében - címü hozzászólásában. Az Európai Unió szerepét előtérbe helyező prezentáció alapgondolat szerint a piac magukat az emberi (fogyasztói) igényeket, szükségleteket és végső soron a szabályozási mintákat is manipulálja. Megkérdőjelezhető ugyanakkor a Paretooptimumra való törekvés létjogosultsága, vagyis kritika tárgyává kell tennünk azt az elképzelést, hogy a vagyoni különbségek növekedése minden további nélkül megengedhető akkor, ha a legszegényebbek helyzete nem romlik. Az előadó az EUB (Európai Unió Bírósága) öko-adó-esetjogát (Frohnleiten, Kernkraftwerke LippeEms, British Aggregates Association ítéletek) elemezve úgy látja, hogy mindig a belső piac és a versenyszabadság érdeke kerekedik felül, amikor konfliktusba kerül a környezetpolitika elveivel és értékeivel. Be kell látnunk, Deák szerint, hogy a piac nem tökéletes; az ökológiai egyensúly biztosítása és a globális szegénység ellene küzdelem jegyében nem több, hanem kevesebb piacra van szükségünk. Az uniós szabályozás gyenge pontjai viszont pont az ilyenfajta konfliktusok megoldása terén mutatkoznak meg.

Harmadikként Nagy Zoltán (habil. egyetemi docens, ME ÁJK) A környezeti adók hatásmechanizmusa, az adók környezeti hatása kérdéskörével igyekezett közpénzügyi szempontból megközelíteni a kérdést, az állami szabályozó szerepre fókuszálva. Előadásában kitért a környezeti adók hatásmechanizmusára, annak lehetséges elönyeire és hátrányaira is. Majd a magyar adórendszerben megtalálható környezeti adók szabályozási és gyakorlati kérdéseit világította meg.

Az előadásokat élénk szakmai vita követte. A hozzászólásokkal számos újabb problémakör, eltérő álláspont is megvilágításra került, mely vélhetöleg hozzájárult a szakmai diskurzus megteremtéséhez, melyet az Albizottság tematikus formában kíván továbbfolytatni több platformon keresztül. 